\title{
RELATIONSHIP BETWEEN BONE MINERAL DENSITY AND BODY COMPOSITION IN ELDERLY
}

\section{RELAÇÃO ENTRE A DENSIDADE MINERAL ÓSSEA E A COMPOSIÇÃO CORPORAL EM IDOSOS}

\author{
Angélica Castilho Alonso ${ }^{1,2}$, Tuane Andreatta Gonçalves ${ }^{1}$, Jenifer Kristina Alves de Almeida ${ }^{2}$, Adriana Machado-Lima ${ }^{1,2}$, \\ Rita de Cássia Ernandes ${ }^{2}$, Julia Maria D'Andréa Greve ${ }^{1}$, Luiz Eugênio Garcez-Leme ${ }^{1,3}$ \\ 1. Movement Study Laboratory, Department of Orthopedics and Traumatology, Hospital das Clinicas HCFMUSP, Faculdade de Medicina, Universidade de São Paulo, São Paulo, SP, Brazil. \\ 2. Department of Graduate Studies in Aging Sciences, Universidade São Judas Tadeu, São Paulo, SP, Brazil. \\ 3. Orthogeriatrics Group, Instituto de Ortopedia e Traumatologia, Hospital das Clinicas HCFMUSP, Faculdade de Medicina, Universidade de São Paulo, São Paulo, SP, Brazil.
}

\section{ABSTRACT}

Objective: To evaluate the association between bone mineral density (BMD) and body composition in healthy older adults at different skeletal sites. Methods: We analyzed 87 medical records and BMD along with the body composition of men ranging from 60 to 87 years of age (mean: 68.5, standard deviation: 6.5). Inclusion criteria were normal BMD values (T-score greater than or equal to -1.0 ) and body mass index within normal or overweight range (18.5 to $\left.29.5 \mathrm{~kg} / \mathrm{m}^{2}\right)$. Body composition was evaluated using bone densitometry with dual-energy X-ray absorptiometry (DEXA) in a LUNAR-DPX apparatus. Results: Greater lean mass, fat mass, and soft tissue was associated with better BMD values in older adults, and higher age was associated with poorer BMD. Conclusion: Body composition (lean and fat masses and soft tissue) in older men is positively associated with BMD at all body sites (arms, legs, and trunk). Level of Evidence II; Prognostic studies - Investigating the effect of a patient characteristic on the outcome of disease.

Keywords: Body composition. Bone density. Densitometry. Osteoporosis. Aged.

\section{RESUMO}

Objetivo: Avaliar a associação entre a DMO e a composição corporal em idosos hígidos em diferentes sítios esqueléticos. Métodos: Foram analisados 87 prontuários e exames de DMO com composição corporal de idosos do sexo masculino com média de idade de $68,5(6,5)$ variando de 60 a 87 anos. Os critérios de inclusão foram valores de DMO dentro do normal (T-score maior ou igual a -1,0); IMC dentro dos valores normais ou sobrepeso $(18,5$ a 29,5 kg/m²). A composição corporal foi avaliada por meio de densitometria óssea por dupla emissão de raios-X (DEXA) em aparelho LUNAR-DPX. Resultados: Quanto maior as massas magra e gorda e os tecidos moles, melhor os valores da DMO dos idosos e quanto maior a idade, pior a qualidade da DMO. Conclusão: A composição corporal (massas magra e gorda e tecidos moles) de homens idosos associa-se positivamente na DMO em todos os locais do corpo (membros superiores, inferiores e tronco). Nível do Evidênci II; Estudos prognósticos - Investigação do efeito de caractetísticas de um paciente sobre o desfecho da doença.

Descritores: Composição corporal. Densidade mineral óssea. Densitometria. Osteoporose. Idoso.

Citation: Alonso AC, Gonçalves TA, Almeida JKA, Machado-Lima A, Ernandes RC, Greve JMD, Garcez-Leme LE. Relationship between bone mineral density and body composition in elderly. Acta Ortop Bras. [online]. 2018;26(1):27-9. Available from URL: http://www.scielo.br/aob.

\section{INTRODUCTION}

According to Rodrigues-Filho et al., ${ }^{1}$ maintenance of bone mineral density (BMD) is very important to prevent osteoporosis, which is characterized by an imbalance between the activity of the osteoblastic and osteoclastic cells; in other words, the matrix and the bone minerals are lost due to excessive bone resorption in comparison with formation.

In order for adequate bone mineralization to occur, three interrelated factors must be present: the levels of circulating hormones that act in the process of calcification, mechanical load imposed on the skeleton, and adequate intake and production of calcium and vitamin D..$^{1,2}$
The prevalence of osteoporosis in the United States is 10.2 million in people aged 50 years or older. The risk of fracture coincides with a high risk of morbidity and early mortality. ${ }^{2}$

In Brazil, a study involving individuals aged 70 years or above found that the prevalence of osteoporosis in the femoral neck was 33\% in women and $16 \%$ in men. ${ }^{3}$

Excess body weight may have a preventive effect and the ability to modify the process of bone resorption. The possibility of developing osteoporosis is known to be lower when the BMI is higher, ${ }^{4}$ but obesity has adverse pathophysiological consequences for the bones and skeletal muscle. For example, the infiltration of intramuscular fat, which is part of the aging process, is associated with muscle weakness, and consequently increased risk of fracture. ${ }^{5-8}$

All authors declare no potential conflict of interest related to this article.

Work conducted at the Movement Study Laboratory, Department of Orthopedics and Traumatology, Hospital das Clinicas HCFMUSP, Faculdade de Medicina, Universidade de São Paulo, São Paulo, SP, Brazil. 
Body weight is substantially composed of lean mass and fat mass, and the relative contribution of these masses to BMD continues to be a controversial issue. ${ }^{1-5,9}$

The goal of this study, therefore, was to assess the association between BMD and body composition in healthy older individuals within normal or overweight BMI ranges at different skeletal sites.

\section{METHODS}

\section{Sample}

We analyzed 87 medical records and BMD evaluations as well as body composition of elderly male group patients in the Geriatrics Group at the Instituto de Ortopedia e Traumatologia (IOT) at the Faculdade de Medicina da Universidade de São Paulo (USP). All the evaluations were performed by a specialized team using the same machine in the IOT Radiology Department and the reports were emitted by the physician in charge from 2001 to 2015. The inclusion criteria were BMD within normal values (T-score greater than or equal to -1.0) and BMI within normal or overweight range (18.5 to $\left.29.5 \mathrm{~kg} / \mathrm{m}^{2}\right)$.

This cross-sectional study was approved by the institutional review board at the Universidade de São Paulo (CAPesq no. 1167/06).

\section{BMD and body composition testing}

Body composition was assessed through densitometry with dual-energy X-ray absorptiometry (DEXA) in a LUNAR-DPX device (Madison Corporation, USA).

\section{Statistical analysis}

The data were entered and analyzed in SPSS 20.0 software. The Kolmogorov-Smirnov test was used to assess whether the continuous quantitative variables presented normal distribution.

Spearman's correlation coefficient was used to correlate the dependent variable (BMD) with the independent variables (anthropometric characteristics and body composition). An alpha of 5\% was used for all statistical tests.

\section{RESULTS}

The characteristics of the individuals who participated in the study are described in Table 1.

The data presented in Table 2 show that age had a negative influence on BMD, with the increased age associated with lower BMD. The anthropometric variables all had a positive correlation with BMD, particularly body mass and consequently BMI, with higher values for body weight and BMI corresponding to an increase in BMD.

Table 3 shows the correlation between BMD in different sites with lean mass, fat mass, and soft tissue, and all these variables showed a positive correlation with BMD.

\section{DISCUSSION}

The main finding of this study was that body composition (lean and fat mass and soft tissue) is associated with BMD in older men.

Table 1. Characteristics of the study population (anthropometric characteristics and age)

\begin{tabular}{c|c|c|c}
\hline \multirow{2}{*}{ Variable } & \multicolumn{3}{|c}{ Older adults } \\
\cline { 2 - 4 } & Mean (SD) & Minimum & Maximum \\
\hline Age (years) & $68.5(6.5)$ & 60 & 87 \\
\hline Anthropometric characteristics & & & \\
\hline Height $(\mathrm{cm})$ & $164.7(5.5)$ & 155 & 180 \\
\hline Weight $(\mathrm{kg})$ & $65.4(7.0)$ & 49 & 81 \\
\hline $\mathrm{BMl}\left(\mathrm{kg} / \mathrm{m}^{2}\right)$ & $24.0(2.2)$ & 19.8 & 29.8 \\
\hline
\end{tabular}

Table 2. Correlation between bone mineral density (BMD) and anthropometric variables.

\begin{tabular}{c|c}
\hline \multirow{2}{*}{ Variable } & Group of older adults \\
\cline { 2 - 2 } & $\mathrm{N}=87$ \\
\hline Age & $\operatorname{BMD}\left(\mathrm{g} / \mathrm{cm}^{2}\right) \mathrm{r}(\mathrm{p})$ \\
\hline Anthropometric characteristic & $-.263(0.01)^{\star}$ \\
\hline Height $(\mathrm{cm})$ & \\
\hline Weight $(\mathrm{kg})$ & $.221(0.04)^{\star}$ \\
\hline $\mathrm{BMl}\left(\mathrm{kg} / \mathrm{m}^{2}\right)$ & $.630(\mathrm{p} \leq 0.001)^{\star}$ \\
\hline
\end{tabular}

$r$-Spearman's correlation coefficient, $p \leq 0.05$. BMD = bone mineral density; $B M l=$ body mass index

Table 3. Correlation between bone mineral density (BMD) and body composition.

\begin{tabular}{|c|c|c|}
\hline & & Group of older adults \\
\hline & & $N=87$ \\
\hline Region & Variable & $\operatorname{BMD}\left(\mathrm{g} / \mathrm{cm}^{2}\right) r(p)$ \\
\hline \multirow{4}{*}{ Arm } & Fat mass (\%) & $.264(0.01)^{*}$ \\
\hline & Soft tissue (g) & $.621(p \leq 0.001)^{*}$ \\
\hline & Fat mass $(\mathrm{g})$ & $.432 p \leq 0.001)^{*}$ \\
\hline & Lean mass $(\mathrm{g})$ & $.579(p \leq 0.001)^{\star}$ \\
\hline \multirow{4}{*}{ Leg } & Fat mass (\%) & $.175(0.11)$ \\
\hline & Soft tissue (g) & $.547(p \leq 0.001)^{\star}$ \\
\hline & Fat mass $(\mathrm{g})$ & $.352(0.01)^{\star}$ \\
\hline & Lean mass ( $\mathrm{g}$ ) & $.472(p \leq 0.001)^{*}$ \\
\hline \multirow{4}{*}{ Trunk } & Fat mass (\%) & $.370(.001)^{*}$ \\
\hline & Soft tissue (g) & $.550(p \leq 0.001) *$ \\
\hline & Fat mass $(\mathrm{g})$ & $.422(p \leq 0.001)^{*}$ \\
\hline & Lean mass (g) & $.482(p \leq 0.001)^{*}$ \\
\hline \multirow{4}{*}{ Body -Total } & Fat mass (\%) & $.340(.002)^{*}$ \\
\hline & Soft tissue (g) & $.600(p \leq 0.001)^{\star}$ \\
\hline & Fat mass $(\mathrm{g})$ & $.439(p \leq 0.001)^{\star}$ \\
\hline & Lean mass (g) & $.528(\mathrm{p} \leq 0.001)^{*}$ \\
\hline
\end{tabular}

$r$ - Spearman's correlation coefficient, $p \leq 0.05$. BMD = bone mineral density.

There was a negative correlation between age and BMD, namely, greater age was correlated with lower BMD, corroborating the work of Biana et al., ${ }^{10}$ who claimed that this mainly occurs at the end of the last decade of life, and may correspond to $5-10 \%$ of total bone mass/decade. The reasons for this may include nutritional deficiencies, some chronic diseases, and lack of exercise.

Lean mass, fat mass, and soft tissue mass were positively associated with BMD. This means that body composition promotes mechanical load on the bone, inducing the formation of osteoblasts and the piezoelectric effect; this positive relationship has already been demonstrated in another study. 5,9,10

It is agreed that lean mass has a positive impact on bone quality;,5-12 in this study lean mass had higher correlation values than the other masses. Plujim et al. ${ }^{10}$ stated that individuals with greater lean mass generally have a more active lifestyle, with more adequate nutritional habits that may have a direct impact on bone health. Furthermore, the studies by Binder et al. ${ }^{11}$ and Vilassa et al. ${ }^{12}$ claimed that greater muscle strength leads to better muscle contraction, in turn impacting specific bone sites to produce specific deformations, and stimulating bone cells that are anatomically related to these muscles, which also explains the piezoelectric effect in the increase of bone mass. Body composition changes significantly in older individuals, including increase and redistribution of adipose tissue; this distribution progressively increases in the abdominal cavity and is less in the 
limbs. Although fat mass also had positive relationships in all sites, this is not the most appropriate way of improving bone quality. According to Zhang et al. ${ }^{13}$ and Sheu et al., ${ }^{14}$ fat (and especially abdominal fat) elevates the risk for metabolic diseases, sarcopenia, and functional decline. Higher levels of visceral fat reduce muscle mass and increase fragility and risk of fracture through intramuscular fat infiltration. ${ }^{13-15}$

The individuals analyzed in this study were within normal or overweight BMI ranges; we found that both lean and fat masses improve bone quality, but more lean mass in the body composition improves bone biomechanics, stimulating osteoblasts and bone cells and may indicate less modification in BMD during the aging process, as stated by Coin et al. ${ }^{16}$

\section{CONCLUSION}

Body composition (lean mass, fat mass, and soft tissue mass) in older men is positively associated with BMD at all sites of the body (arms, legs, and trunk).

AUTHORS' CONTRIBUTIONS: Each author made significant individual contributions to this manuscript. ACA (0000-0002-9644-5068)* was the lead author, analyzed the data and constructed the article; TAG (0000-0002-3518-6111)* tabulated the data and assisted in constructing the article; AML $(0000-0002-5741-3418)^{*}$ assisted in constructing the article; JKAA (0000-0001-9658-0166)* assisted in constructing the article and was responsible for submission; RCE (0000-0003-2272-5320* assisted in constructing the article; LEGL (0000-0002-9738-5466)* was the doctor responsible for requesting, collecting, and analyzing the exams and made final corrections to the work. All authors approved the final version of the manuscript. *ORCID (Open Researcher and Contributor ID).

\section{REFERENCES}

1. Rodrigues Filho EA, Santos MA, Silva AT, Farah BQ, Costa MC, Campos FA, et al. Relação entre composição corporal e densidade mineral óssea em jovens universitários com diferentes estados nutricionais. Einstein. 2016;14(1):12-7.

2. Johnell O, Kanis JA. An estimate of the worldwide prevalence and disability associated with osteoporotic fractures. Osteoporos Int. 2006;17(12): 1726-33.

3. Camargo MB, Cendoroglo MS, Ramos LR, de Oliveira Latorre MR, Saraiva GL, Lage A, et al. Bone mineral density and osteoporosis among a predominantly Caucasian elderly population in the city of São Paulo, Brazil. Osteoporos Int. 2005; 16(11):1451-60.

4. Van Langendonck L, Claessens AL, Lefevre J, Thomis M, Philippaerts R, Delvaux $\mathrm{K}$, et al. Association between bone mineral density(DXA), body structure, and body composition in middle-aged men. Am J Hum Biol. 2002;14(6):735-42.

5. Chaves LM, Gomes L, Oliveira RJ, MB Marques. Relação entre variáveis da composição corporal e densidade mineral óssea em mulheres idosas. Rev Bras Med Esp. 2005;11(6):319-23.

6. Ozeraitiene V, Butenaite V. The evaluation of bone mineral density based on nutritional status, age, and anthropometric parameters in elderly women. Medicina (Kaunas). 2006;42(10):836-42.

7. Wong AK, Beattie KA, Min KK, Gordon C, Pickard L, Papaioannou A, et al Canadian Multicentre Osteoporosis Study (CaMos) Research Group. Peripheral quantitative computed tomography-derived muscle density and peripheral magnetic resonance imaging-derived muscle adiposity: precision and associations with fragility fractures in women. J Musculoskelet Neuronal Interact. 2014;14(4):401-10.

8. Bian P, Li X, Ying Q, Chen J, Jin X, Yao J, et al. Factors associated with low femoral neck bone mineral density in very elderly Chinese males. Arch Geronto Geriatr. 2015;61(3):484-8.

9. Ho-Pham LT, Nguyen ND, Lai TQ, Nguyen TV. Contributions of lean mass and fat mass to bone mineral density: a study in postmenopausal women. BMC Musculoskelet Disord. 2010;11:59.

10. Pluijm SM, Visser M, Smit JH, Popp-Snijders C, Roos JC, Lips P. Determinants of bone mineral density in older men and women: body composition as mediator. J Bone Miner Res. 2001;16(11):2142-51.

11. Binder EF, Kohrt WM. Relationships between body composition and bone mineral content and density in older women and men. Clin Exerc Physiol 2000;2:84-91.

12. Vilassa KHC, Ferriolli E, Lima NKC, Paula FJA, Marchini JS, Moriguti JC. Força muscular e densidade mineral óssea em idosos eutróficos e desnutridos. Rev Nutr Campinas. 2011;24(6):845-52.

13. Zhang P, Peterson M, Su GL, Wang SC. Visceral adiposity is negatively associated with bone density and muscle attenuation. Am J Clin Nutr. 2015;101(2):337-43.

14. Sheu Y, Marshall LM, Holton KF, Caserotti P, Boudreau RM, Strotmeyer ES, et al. The Osteoporotic Fractures in Men (MrOS) Research Group. Abdominal body composition measured by quantitative computed tomography and risk of non-spine fractures: the Osteoporotic Fractures in Men (MrOS) study. Osteoporos Int. 2013;24(8):2231-41.

15. Song HJ, Oh S, Quan S, Ryu OH, Jeong JY, Hong KS, et al. Gender differences in adiponectin levels and body composition in older adults: Hallym aging study. BMC Geriatr. 2014;14:8.

16. Coin A, Sergi G, Benincà P, Lupoli L, Cinti G, Ferrara L, et al. Bone mineral density and body composition in underweight and normal elderly subjects. Osteoporos Int. 2000;11(12):1043-50 